\title{
MS2 Quantification by Isotope Labeling
}

National Cancer Institute

\section{Source}

National Cancer Institute. MS2 Quantification by Isotope Labeling. NCI Thesaurus. Code C161816.

A proteomic quantitation method where isotopically-labeled peptides are quantified during a second round of mass spectrometry (tandem mass spectrometry). 